\title{
Entrepreneurial Characteristics in SMEs: A Rural and Remote Rural Perspective of Lincolnshire Businesses, Part $2^{1}$
}

\author{
Kevin Blanchard \\ Lincoln Business School, University of Lincoln, UK
}

\section{Businesses located within remote}

areas have better-developed skills and characteristics, which may be termed entrepreneurial in nature.

Rural businesses have a better understanding of their customer needs and requirements.

SMEs do not see themselves as different in any way from other businesses.
B usinesses in remote rural locations have sustained greater levels of growth and have suffered less within the period of the recession.

The term 'entrepreneur,' or being entrepreneurial, has changed from the early debates of the 1970s to now include many different connotations and meanings (Wang and Altinay, 2012). Previously, the term was used to epitomize excellence in business acumen, performance, and also free thinking; now, it seems to cover all manner of references, including TV celebrity, where 'entrepreneurs' give cash away in a game show format (Hollows and Jones, 2010). During this long transition and transformation from a meaningful marker of excellence to a less than informative indicator of mediocrity, the term underwent a form of metamorphization. During this transition, it seems to have acquired a form of elasticity, and is now used to describe an extraordinary and well-performing business owner; a non-descript person who has achieved very little and in so doing, it transports them to a higher status within people's perception, through media misinformation (Hollows and Jones, 2010).

This article is a follow-up to Blanchard (2013) in this journal, building upon previous research carried out by the author over a 10-year period (Blanchard, 2010). The aim is to examine if entrepreneurial businesses have survived over this period better than others. Some key entrepreneurial areas will be discussed as they are important to show how both rural and remote rural small and medium enterprises (SMEs) use these characteristics to their advantage. This will be shown within the analysis.

\section{Entrepreneurial antecedence}

It is with the intervention of the media status that the term becomes divorced and devoid of its origins as the mediator/facilitator of goods or services (Cantillon, 1931). It also loses any connection with and relationship to superior performance

\footnotetext{
${ }^{1}$ JEL classification codes: E44, F21, F32, F43, O16.
} 
exhibited by the individual and also the traditional and debated entrepreneurial notion, that the entrepreneur may have characteristics or traits. Research argues that the earliest interpretation of the word 'entrepreneurship' has its origins substantiated and embedded within the community (Cantillon, 1931). Today, the term has little relationship with its ancestry and is used to describe a form of behavior hyped by the media; in so doing, the term has become somewhat watered down, devoid of any rigor, and has become meaningless within the context of extraordinary behavior and its academic origins and roots. It is within foundation knowledge that sound entrepreneurial theory needs to be established on both what constitutes entrepreneurialism, and how this may differ from managerial experience.

Many authors, including Marshall (1920), Goffee and Scase (1987), and McKenzie et al. (2007), advocated that the advancement of individuals emerges out of the development of other people and organizations. They argue that this development transforms the individual to be able to both spot and take advantage of opportunities over the advancement of others. By adopting this approach, one must distinguish theory from training, and should not confuse them with both innate and latent talents, from which many key theorists' beliefs emerge. What is being described here is a process of developing either latent or embedded abilities; this culminates when individuals attain a given level of entrepreneurability, within both their decision making and daily business life. Having these highly developed skills enables the business owner to outperform other businesses within certain geographical locations, giving them an advantage over others.

Taken from a business perspective, the research question concerns whether the same view is applicable in all situations. Are rural and remote businesses a special case or just the same as any other small business? To address this question, comparisons need to be made between both rural and remote businesses, which in turn would lead to an examination of the skills sets used by businesses within each location.
The figure of the entrepreneur can be associated and aligned with that of Marshall (1920), where entrepreneurship (not necessarily business) can be seen as progressing in an incremental way. This viewpoint builds upon Schumpeter (1934), who stated that the innovator acts as a dynamic agent for both the economy and change. This theory and debate is interesting when applied to small businesses and the rural economy, where in some cases it has been established that small rural firms need a catalyst in order to grow (Goetz et al., 2010). The catalyst in this situation can be in the form of the innovative business owner, who has not only spotted the opportunity over others, but more importantly and differentially, also acted upon it (McKenzie et al., 2007). Adopting such a view can be aligned and equated within a rural framework, as it may go some way in explaining how local environmental dynamics can create opportunities where the individual both sees and acts upon ideas and opportunities in direct relation to their potential skills base - to a greater or lesser degree (Gartner, 1988). It may also be argued that this is not purely the domain of the rural entrepreneur, it may and often does take place within an urban environment where individuals with some entrepreneurial flair may act upon their potential, and in so doing establish a successful business. What needs to be fully understood is that the environment both businesses operate in is different; not just the geographical location. The vibrancies of one are not translated or interchangeable with the other. It is the rural entrepreneur who has to be more alert to their environment; as Kirzner (2008) states, they need to fully understand their customers' requirements and deliver in an effective way.

The rural entrepreneur may receive a lower impact from their environment in the form of proximity to their customer base, and consequently they display a higherdeveloped level of entrepreneurial characteristic. This is not the case with the urban business owner (Blanchard, 2013). It also needs to be stated that these actions made within a rural or remote environment are less prevalent, due purely to the proximity of other businesses. This in 
turn offers little or no catalyst for other businesses to feed off. Therefore, the level of entrepreneurial stamina needs to be far greater when operating a business within such an environment. In contrast, the urban operator has a greater degree of footfall. A larger potential customer base is possible for these businesses.

It is through the level of reaction and interaction that the type of environment may be denoted, and have some bearing on the type of entrepreneur both choosing and operating within it. Schumpeter (1943) stated that disequilibrium can bring about opportunities. With this view it may be noted that entrepreneurs can have some level of influence upon the environment, according to their level of entrepreneurial ability (Markantoni et al., 2013). An approach of this nature offers the potential that entrepreneurs may gain valuable experience within their business associations, which result in the development of their respective skills through a network process of information gained through various sources. By adopting this argument it could be proposed that the entrepreneur with the higher-developed skills base could have a greater degree of influence over their operating environment. In addition, prolific entrepreneurs may act upon these opportunities to establish a level of normality and transient knowledge where networks are in close proximity and the development of the business is done over a longer period of time. Recent research has established that this is the case within remote rural environments, in that some businesses do hone and develop certain skills in order to both develop and, in some cases, survive. In most cases this is done by offering exceptional customer service and being able to both spot and act upon opportunities, dependent upon the entrepreneurial skills of the business owner. Research also shows that there is a strong correlation between the number of characteristics displayed by the owner and the success of the business (Blanchard, 2013). However, the debate needs to be placed firmly in the context of the academic argument, rather than from the viewpoint of the business owner (Timmons, 1994). It is only through an understanding of the relationship between entrepreneurial characteristics and business performance that we can begin to understand the effects that the operating environment may have on any outcomes. Whether the location is remote or rural, the skills base will be different, operating and exhibiting different dynamics. Only through the examination of skills, and applying an analysis to understand the differentiation between them, can we begin to understand and differentiate why some business owners specifically choose their geographical location over others, and as a result, are more successful than others operating within it. When a debate is configured within a rural or remote rural environment, many SME owners recognize that transient knowledge transfer can take place within a customer-service perspective. This transfer of knowledge may help to build a relationship and in some situations and conditions, furnish the local network with an element of trust and commitment toward the business owner, thus establishing a level of business one-up-man-ship over rivals within the local business hierarchy. These actions can be closely linked to the characteristic profile of the business owner, where the broader the dynamic, the more innovative the practices used (Blanchard, 2013).

\section{Rural enterprise - elements of theory}

Within the UK, 99.3\% of all businesses are classed as small, contributing $51 \%$ of GDP to the economy and employing $58 \%$ of the private-sector workforce (Federation of Small Businesses, 2012). Some 28\% of small firms $-513,000$ businesses - operate in rural-area markets (DTI, 2010), whereas the rural economy supports 5.4 million employees, $74 \%$ of these on a full-time basis (Office for National Statistics, 2013). There are more registered businesses per head of population in predominantly rural areas than in urban areas, reflecting there being a greater number of smaller businesses in rural areas. Between 2007 and 2010, there was a general decrease in the rate of registered business start-ups per head, reflecting the economic downturn, but the rates across all area types 
have since become stable or have increased. Since 2008 there have been more business start-ups per head of population in predominantly urban areas than in predominantly rural areas (Benyon, 2015).

The data suggests that due to population density, it may be easier to start a business within an urban location. This needs to be placed in context; both rural and remote areas are also seeing an increase in people wishing to locate and start enterprises within these locations, with $18.9 \%$ $(9.8 \mathrm{M})$ of the UK population and $1.2 \%(620,000)$ of them living within areas classed as remote (Federation of Small Businesses, 2012). Since 2012/13, there has been an increase of $2.3 \%$ in the number of local units of registered businesses in all rural areas, compared with increases of 4.6\% in all urban areas and 4\% in England (Benyon, 2015).

Research has established, in relation to the rural business owner, that some forms of innovative activity may be more prevalent in individuals who exhibit a broader subset of other characteristics. These characteristics have been found to include a number that may be termed entrepreneurial (Varande et al., 2009), which may include some people having higher levels of creativity or being willing and able to take higher risks and so being able to both spot and take advantage of opportunities within various economic cycles (Esparcia, 2013; Gudmundson et al., 2003). Chell $(1997,1998)$ further builds upon the argument by endorsing the idea that entrepreneurial businesses are driven by a person who is both alert to opportunities and acts upon them for the pursuit of capital gain.

When placing this theory within a geographical context, the role of the innovative business owner may be seen as a central factor and catalyst for the establishment, diversification, and increased competitiveness within a region, and also the development of local networks (Esparcia, 2013). This theoretical debate also highlights the level of individual abilities and characteristics which need to be exhibited in order to offer any form of influence. When viewed within a holistic framework, local networks may well be termed entrepreneurial due to the added effect of identifying and using them within a specific environment (Brandstätter, 2011).

Furthermore, McKenzie et al. (2007) suggest that further development is needed within the present ideal of the individual as the entrepreneur, considering a remit where groups of like-minded people are brought within the debate. The UK government introduced 'Rural Growth Networks,' launched in 2012, with the aim of allowing both micro and SME businesses access to funding and expertise so as to foster growth within a specific community (DEFRA, 2012). The idea of groups seeking to both develop and take advantage of, and also act upon, similar opportunities in a holistic manner is not presently viewed as being entrepreneurial from the traditional viewpoint. By adopting this change, it would provide an opportunity to move the debate away from the individual, toward a more collective ideal, where the theory of network development and skills gaps can be debated to examine how localized networks operate on a system of knowledge transfer and trust (Smith and Lohrke, 2008).

Beaver (2003) gives evidence that many SMEs operate within localized markets, which have a well-established and ordered customer base, but have no influence over their specific sector. These findings are not fully confirmed by Hannon (2005), who suggests that the geographical location of a market can influence a firm's performance, but influence their specific market sector, due to the nature of the competition. Bosworth (2009) also intimates that, on balance, the empirical evidence indicates that firms located within accessible rural areas can grow more rapidly than firms located both in urban and remote rural areas, as a result of expanding their customer base and so having more influence over it. These findings help to reinforce the argument that SMEs based within accessible locations have a distinct advantage over others. This also strengthens the debate that SMEs operating within remote and rural areas need to have heightened characteristics and skills in order to stay in business. This is the case with many rural enterprises, and is due to them operating in sparsely populated areas which have no industrial 
infrastructure in relation to their trading area - giving the entrepreneur an opportunity to capitalize on the local demography. It also needs to be mentioned that this is not the case within urban locations.

These businesses do exhibit a local influence over their sector, and offer a form of control of the supply and price of goods and services within their area. The influence is controlled by offering superior customer service, wellestablished networks, and the use of entrepreneurial marketing techniques, which in some cases 'control' local markets (Blanchard, 2010). It is also noted that the location and controlling aspects of SMEs in respect of their business trading can have an influence over their resilience to recession (Dixon and Clifford, 2007). These business owners also help with the introduction of new goods or services due to the level of understanding of the changing needs and demography of their customer base; these may also help to build upon the skills needed for survival in both rural and remote locations (Kitching and Smallbone, 2012). When these skills are achieved, they offer the entrepreneur a distinct advantage over other businesses, but this can only be achieved through the level of alertness exhibited by the individual and their willingness and ability to change. The level of characteristic exhibited by SME owners can play a significant part within both the success and performance of a business (Corman et al., 1996; Kirby, 2003). Allinson et al. (2000) argue that employment can come from the growth of the entrepreneurial business, either by the owner-manager growing their business or the SME recognizing and exploiting opportunities for growth potential.

Over the last two decades, small business strategies have been debated and evaluated by various authors in a bid to establish if actions of a certain type may influence the desired path of a business. Smallbone and North (1995) found that there was no single strategy that could either influence or establish a pattern of growth for a business. They also confirmed that strategy needs to be viewed as a collective action, made through both the vision and knowledge of business owners having a composite of characteristics. This again adds to the argument for effective networks within both rural and remote areas, where the entrepreneur who recognizes opportunities is at a distinct advantage over others. An area that has proven to be valid within the strategic vision of businesses is that of innovation; within its many forms and areas of business talent, the specific notion is that a business active within innovation performs far better than those businesses not so active (Smallbone and North, 1995; Sriram et al., 2007). The identification of key areas of entrepreneurial ability forms part of the methodological framework of this study.

When Beaver (2003) stated that small businesses may have little or no influence over their sector or locality, this debate needs to be viewed in relation to other theories and empirical evidence including cluster theory and niche markets. Clustering and self-employment have largely been held as a main indicator of successful small-firm development and a key driver in the growth of businesses; the main viewpoint on this can be seen with Marshall's ideal (Marshall, 1920). Research further states that businesses can develop and grow through a form of information transfer, which is exhibited through the nature of similar businesses located within areas of specific resources and markets (Atherton and Hannon, 2005). The empirical research in this type of study has largely been conducted within large towns or cities, and little research has been forthcoming in a remote rural or rural setting. The heritage of these two areas is also closely linked to the theory of Granovetter (1985) and Birley (1985), which states that the needs of these areas can be of a similar nature and operate along the same lines. Both are concerned with 'social embedded ties' that can be, and often are, established within small businesses and their communities through the social and psychological networks built on these foundations. Research has also found that they are often the main drivers of the establishment and growth of such operations, operating within the proximity of similar businesses, where the networks are often small and most owners know of each other or have strong linkages (Smith and Stevens, 2010). Within clusters, 
various synergies often take place and as a result, rapid growth may occur through the transfer of both tacit and direct knowledge. When this takes place within a rural or remote environment, it can often cause problems through the number of individuals holding either key skills or knowledge directly related to the performance of the business.

Gray (1993) indicated that certain factors can have a limiting effect on the growth potential of some businesses, through the level of knowledge and skills being placed within a small number of individuals (this can prove detrimental if they move to a rival). It is often for this reason that SME owners try to offer more to their employees than a reasonable salary. Businesses located within a rural or remote environment often have a well-developed infrastructure and close ties to the local community, allowing them to establish self-reliance for mutual survival (Steyaert and Katz, 2004). Self-reliance can often be communicated through the needs of the business and community, and may take the form of sponsorship of football teams or school events. In this way, a link often develops between the parties by forming a reciprocal trust, which can be exploited by the business in order to grow and in so doing limit the expansion or infiltration of urban business. It is through the implementation of this type of mechanism that many remote and rural businesses both build and grow, and in so doing secure a strong embeddedness within local communities which often survives an adverse economic climate that may otherwise destroy businesses without these infrastructures (Jack and Anderson, 2002).

\section{Methodology}

This article builds upon a study that forms part of a 10year linear process examining entrepreneurial characteristics of SME businesses within a rural/remote location in the county of Lincolnshire. The brief aim of the research was to revisit the original sample in order to examine how/ if the businesses had changed over the 10-year period and to further examine any identified change. The key measures used in the new survey were the same as in the original: innovation, opportunity spotting, and risk.

The original study consisted of 25 randomly selected remote and rural businesses, based on the study definition and geographical classification of rural and remote locations, rural 80 (DEFRA, 2014). Within this category, some businesses fall into the 'remote section,' where the location is predominantly rural and consists of a lowdensity population. The follow-up study visited the original 25 SME businesses (only 21 still operating), asking 10 questions from the original survey, which were centered on examining how trading had changed over the survey period. Five new questions were added to provide information in order to measure both the performance and reasoning behind any changes.

The chosen method of data collection was a semistructured face-to-face interview which aimed to offer a measure between the samples; this would also allow for any ad-hoc data to be used within further follow-up data analysis. The questions were formed into two separate themes, one centered around entrepreneurial characteristics and the other around business growth, in order to indicate if entrepreneurial characteristics had any influence on business performance.

Out of the original survey sample of 25 , only 21 businesses were still trading in 2014, with a split of 13 remote rural and 8 rural businesses respectively (Table $\mathbf{1}$ ).

Table 2 offers a breakdown of the type, number of employees, and location associated with each activity.

\section{Findings}

The original data identified that remotely located businesses performed equally as well as those trading within a

Table 1. Businesses trading 2004/14 per location

Total number of businesses in the original survey 25

Number of businesses still trading in 2014

Number of remote businesses still trading

Number of rural businesses still trading 
Table 2. Number of employees/business/location

$\begin{array}{llrl}\text { Business type } & \text { Number of businesses } & \text { Number of employees } & \text { Business location } \\ \text { Direct farming related } & 7 & 35 & \text { Remote rural } \\ \text { Indirect farming related } & 6 & 55 & \text { Rural + remote } \\ \text { Manufacturing } & 3 & 105 & \text { Rural } \\ \text { Retail } & 1 & 2 & \text { Rural } \\ \text { Service sector } & 1 & 22 & \text { Rural } \\ \text { Construction } & 4 & 302 & \text { Rural } \\ \text { Brewing } & 1 & 25 & \text { Remote rural } \\ \text { Distribution } & 1 & 36 & \text { Remote rural } \\ \text { Hospitality } & 1 & 15 & \text { Rural } \\ \text { Total } & \mathbf{2 5} & \mathbf{5 9 7} & \end{array}$

rural environment, and that the geographical location did not have any identifiable detrimental effect on business performance. The composite scores formulated in the original survey also identified that business owners within the original survey sample with a Shackle entrepreneurial orientation performed better in a remote rural environment than a semi-rural or urban one (Blanchard, 2013; Shackle, 1970).

Building upon the previous research, the new survey continued to use the six original entrepreneurial areas of test, but in a more simplified form using a Likert-type scale formulation. Within the original survey a composite was formed which comprised a Likert scale (1-7) along with qualitative question formats which required normalization. The chosen method conformed to the understanding of Gitta et al. (2004), in that the 'yes' and 'no' replies were inserted into a Likert scale, with extremities of 1 and 7; the 'no' reply became 3 and the 'yes' reply 6 . This method enabled the data to be standardized and aggregated, with percentages being calculated.
Table 3 displays the percentage of businesses which exhibited the specific entrepreneurial characteristic. The data shows a clear indication that the three main test areas - innovation, opportunity spotting, and risk - from the original survey were still viewed as key areas to business success in 2014. The data shows that these were identified as being the most important and used characteristics by business owners, which they felt to offer them a level of performance linked to their business strategy.

The survey sample was not a 50/50 split of both rural and remote businesses, which could result in the data being skewed slightly due to some operations having ceased trading. Table 4 clearly shows that the number of business owners exhibiting key entrepreneurial skills including innovation, opportunity spotting, and risk taking - is higher amongst those trading in remotely located areas. The results also confer with the literature by confirming that businesses within remote geographical locations do have a higher degree of entrepreneurial awareness than those in other areas. This could mean that

Table 3. Percentage of businesses displaying entrepreneurial characteristics by type

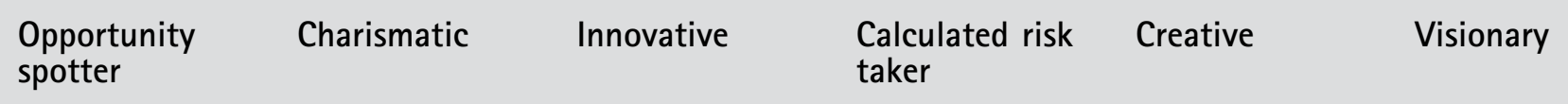

$\begin{array}{llllll}82.3 & 28.6 & 85.8 & 61.9 & 61.9 & 89.9\end{array}$ 
Table 4. Percentage of businesses displaying entrepreneurial characteristics by geographical location

$\begin{array}{lllllll} & \begin{array}{l}\text { Opportunity } \\ \text { spotter }\end{array} & \text { Charismatic } & \text { Innovative } & \begin{array}{l}\text { Calculated } \\ \text { risk taker }\end{array} & \text { Creative } & \text { Visionary } \\ \text { Remote } & 75 & 58 & 81 & 78 & 63 & 52 \\ \text { Rural } & 25 & 42 & 19 & 22 & 37 & 48\end{array}$

business owners who choose to locate within a remote setting are using the knowledge that they will incur less direct competition. The significance within the skills between the two locations is highest within four areas, the three main areas, plus creativity.

Table 5 shows that businesses located within a rural setting felt that their location had an effect on the performance of their business over a 10 -year period, whereas businesses trading in a remote rural setting indicated that location had less of an impact on their business performance. The findings reveal that business owners within a rural setting have found difficulties in trading which can be directly associated with their location. The owners further felt that being in proximity to other businesses made for greater competition and loss of profitability during the recession; therefore, their overall profitability has suffered as a consequence. In contrast, businesses within a remote setting felt that location had little effect on their business activities.

The data also suggests that business location does have an actual effect on performance in so far as businesses report that trading and location are linked. Rurally located business owners do not state that a perceived trading difficulty takes place; rather, they state that their trade is either static or falling. By contrast, remotely located businesses state that trade is growing slightly and that location is no barrier to further growth. When these views are analyzed with other data taken from the survey, it becomes apparent that traders within the remotely located areas have better-developed entrepreneurial characteristics and, through this, are able to spot and act upon opportunities more quickly.

\section{Conclusion}

The analysis of the sample data classified by the six main entrepreneurial characteristics has revealed quite distinctly that businesses located within a remote setting report better trading than those in other locations. During the survey period, which includes the recession period of 2008 , it is remarkable to see that remotely located businesses experienced an increase in trading. The data also reports that there is a difference between the two areas and that this has been confirmed over a 10-year period. The data further shows that there is a direct response to the entrepreneurial test areas, in that it can be seen that business owners who have a better understanding of customers' needs, and relate these to identified skills in an

Table 5. Percentage of businesses that feel location had a performance impact

Do you feel that the geographical location of your business has had any influence on its performance since 2005?

$\begin{array}{lccr} & \text { None } & \text { Little } & \text { Great } \\ \text { Rural } & 22 & 38 & 40 \\ \text { Remote } & 58 & 38 & 4\end{array}$


entrepreneurial manner, tend to grow their business at a greater rate than those who do not.

It can be argued that business owners in remote areas have a better understanding of their surroundings and the needs of their area, and linking these together through innovative ideas; they are also creative in their trading habits, practices, and initiatives. The results confirm that this type of enterprise is better equipped to withstand severe trading conditions and, in some situations, both grow and diversify. They are operated by people who have a different mindset to others, who are more attuned to their surroundings and able to initiate a plan effectively.

The data corroborates that business owners in both rural and remote settings do not view themselves as being different in any way; they just state that they feel they are more attuned to their customers' needs and requirements. While these views are placed within the definition of entrepreneurial characteristics, it may generally be recognized that the business owners who have well-developed, appropriate skills are able to both survive and grow their business in areas where others struggle and often fail.

\section{References}

Allinson CW, Chell E, Hayes J. 2000. Intuition and entrepreneurial behaviour. European Journal of Work and Organisational Psychology 9(1): 31-43.

Atherton A, Hannon PD. 2005. Localised strategies for supporting incubation: Strategies arising from a case of rural enterprise development. Journal of Small Business and Enterprise Development 13(1): 48-61.

Beaver G. 2003. Small Business, Entrepreneurship and Enterprise Development. Prentice Hall: Harlow, Essex.

Benyon R. 2015. Department for Environment, Food \& Rural Affairs (DEFRA). Rural Economy Report UK. Available at: http://www.publications.parliament.uk/pa/cm201314/cmselect/cmenvfru/602/60207.htm\#n99.

Birley S. 1985. The role of networks in the entrepreneurial process. Journal of Business Venturing 12(1): 101-117.

Blanchard K. 2010. Entrepreneurship within SME's in urban, AQ2 rural and remote rural locations in Lincolnshire. PhD thesis.
Blanchard K. 2013. Entrepreneurial characteristics in SMEs: A rural, remote rural and urban perspective of Lincolnshire businesses, Part 1. Strategic Change 22(3\&4): 191-201.

Bosworth G. 2009. Commercial counterurbanisation: An emerging force in rural economic development. Environment and Planning A 42(4): 966-981.

Brandstätter H. 2011. Personality aspects of entrepreneurship: A look at five meta-analyses. Personality and Individual Differences 51(3): 222-230.

Cantillon R. 1931. Essays on the General Nature of Commerce (edited and translated by H Higgs). Macmillan: London.

Chell E. 1997. The social construction of the entrepreneurial personality. Paper presented at the British Academy of Management Conference, London.

Chell E. 1998. The critical incident technique. In Symonds G, Cassell C (eds), Qualitative Methods and Analysis in Organisational Research: A Practical Guide. Sage: London.

Corman J, Lussier RN, Nolan K. 1996. Factors that encourage entrepreneurial start-ups and existing firm expansion: A longitudinal study comparing recession and expansion periods. Academy of Entrepreneurship Journal 1(2): 43-55.

DEFRA. 2012. Report: Pilot of rural growth networks. Department for Environment, Food \& Rural Affairs. Available at: http://www.publications.parliament.uk/pa/cm201314/cmselect/cmenvfru/602/60207.htm\#n99.

DEFRA. 2014. Introductory guide to rural-urban classification of local authorities. Department for Environment, Food \& Rural Affairs. Available at: http://www.defra.gov.uk/rural/ what-is-rural/rural-urban-classification.

Dixon S, Clifford A. 2007. Ecopreneurship - a new approach to managing the triple bottom line. Journal of Organizational Change Management 20(3): 326-345.

DTI. 2010. A Government Action Plan for Small Business: The evidence base. Small Business Service Report, Department for Trade \& Industry. SBS/DTI, London.

Esparcia J. 2013. Innovation and networks in rural areas. An analysis of innovation from European projects. Journal of Rural Studies 34(1): 1-14.

Federation of Small Businesses. 2012. The Missing Links, Revitalising Our Rural Economy. Report. Available at: http://www .fsb.org.uk/policy/. 
Gartner WB. 1988. 'Who is an entrepreneur?' is the wrong question. American Journal of Small Business 12(4): 11-32.

Gitta HL, Muthén BO. 2004. Applying multigroup confirmatory factor models for continuous outcomes to Likert scale data complicates meaningful group comparisons. Structural Equation Modelling: A Multidisciplinary Journal 11(4): 514-534.

Goetz J, Partridge M, Deller SC, Fleming DA. 2010. Evaluating U.S. rural entrepreneurship policy. Journal of Regional Analysis and Policy 40(1): 20-33.

Goffee R, Scase R. 1987. Introduction. In Goffee R, Scase R (eds), Entrepreneurship in Europe: The Social Processes. Croom Helm: London (reprinted by Routledge: London, 2015).

Granovetter M. 1985. Economic action and social structure: The problem of embeddedness. American Journal of Sociology 19(3): 481-510.

Gray C. 1993. Growth-orientation and the small firm. In Caley K, Chell E, Chittenden F, Mason C (eds), Small Enterprise Development: Policy and Practice in Action. Paul Chapman: London.

Gudmundson D, Tower CB, Hartman EA. 2003. Innovation in small businesses: Culture and ownership structure do matter. Journal of Developmental Entrepreneurship 8(1): 1-17.

Hannon P. 2005. Incubation policy and practice: Building practitioner and professional capability. Journal of Small Business and Enterprise Development 12(1): 57-75.

Hollows J, Jones S. 2010. 'At least he's doing something': Moral entrepreneurship and individual responsibility in Jamie's ministry of food. European Journal of Cultural Studies 13(3): 307-322.

Jack SL, Anderson AR. 2002. The effects of embeddedness on the entrepreneurial process. Journal of Business Venturing 17(5): 467-487.

Kirby DA. 2003. Entrepreneurship. McGraw-Hill: London.

Kirzner I. 2008. The alert and creative entrepreneur: A clarification. Research Institute of Industrial Economics. Working Paper No. 760.

Kitching J, Smallbone D. 2012. Are freelancers a neglected form of small business? Journal of Small Business and Enterprise Development 19(1): 74-91.
Markantoni M, Strijker D, Koster S. 2013. Growth expectations for side activities in rural areas. Journal of Small Business and Enterprise Development 20(3): 584-602.

Marshall A. 1920. Principles of Economics, 8th edn. Macmillan: London.

McKenzie B, Ugbah SD, Smothers N. 2007. 'Who is an entrepreneur?' Is it still the wrong question? Academy of Entrepreneurship Journal 13(1): 23-35.

Office for National Statistics. 2013. Annual Business Survey 2010. DEFRA, Statistical Digest of Rural England, April.

Office for National Statistics. 2014. Annual Business Survey 2014. DEFRA, Statistical Digest of VAT Registrations Within the UK.

Schumpeter JA. 1934. The Theory of Economic Development: An inquiry into profits, capital, credit, interest and the business cycle. Harvard University Press: Cambridge, MA.

Schumpeter JA. 1943. Capitalism, Socialism and Democracy. Harper: New York.

Shackle GLS. 1970. Expectation, Enterprise and Profit. George Allen and Unwin: London.

Smallbone D, North D. 1995. Targeting established SMEs: Does their age matter? International Small Business Journal 13(3): 47-64.

Smith DA, Lohrke FT. 2008. Entrepreneurial network development: Trusting in the process. Journal of Business Research 61(4): 315-322.

Smith BR, Stevens CE. 2010. Different types of social entrepreneurship: The role of geography and embeddedness on the measurement and scaling of social value. Journal of Entrepreneurship and Regional Development 22(6): 1464-5115.

Sriram V, Mersha T, Herron L. 2007. Drivers of urban entrepreneurship: An integrative model. International Journal of Entrepreneurial Behaviour \& Research 13(4): 235-251.

Steyaert C, Katz J. 2004. Reclaiming the space of entrepreneurship in society: Geographical, discursive and social dimensions. Journal of Entrepreneurship and Regional Development 16(3): 193-203.

Storey DJ. 1994. Understanding the Small Business Sector. Routledge: London. 
Thomas A, Mancino A. 2007. The relationship between entrepreneurial characteristics, firms positioning and local development. Journal of Entrepreneurship and Innovation 8(2): AQ5 105-114.

Timmons J. 1994. New Venture Creation, 4th edn. Irwin: Burr Ridge, IL.
Varande V, De Jong JP, Vanhaverbeke W, de Rochemont M. 2009 Open innovation in SMEs: Trends, motives and management challenges. Technovation 29: 423-437.

Wang C, Altinay L. 2012. Social embeddedness, entrepreneurial orientation and firm growth in ethnic minority small businesses in the United Kingdom. International Small Business Journal 30(3): 3-23.

\section{BIOGRAPHICAL NOTE}

Kevin Blanchard is a senior lecturer within Lincoln Business School. His interests are centered on and include research into the entrepreneurial behavior of rural SMEs and entrepreneurial skills.
Correspondence to:

Kevin Blanchard Lincoln Business School

University of Lincoln Brayford Pool, Lincoln LN6 7TS, UK email: kblanchard@lincoln.ac.uk 


\section{AUTHOR QUERY FORM}

Dear Author,

During the preparation of your manuscript for publication, the questions listed below have arisen. Please attend to these matters and return this form with your proof.

Many thanks for your assistance.

\begin{tabular}{|c|c|c|}
\hline $\begin{array}{l}\text { Query } \\
\text { References }\end{array}$ & Query & Remarks \\
\hline AQ1 & $\begin{array}{l}\text { Please check sense: "the geographical location ... can influence ..., but } \\
\text { influence"? }\end{array}$ & \\
\hline $\mathrm{AQ} 2$ & Where was your $\mathrm{PhD}$ thesis undertaken? Please give place of study. & \\
\hline AQ3 & $\begin{array}{l}\text { Office for National Statistics (2014) not cited in text. Please add text } \\
\text { citation or the reference will be deleted. }\end{array}$ & \\
\hline AQ4 & $\begin{array}{l}\text { Storey (1994) not cited in text. Please add text citation or the } \\
\text { reference will be deleted. }\end{array}$ & \\
\hline AQ5 & $\begin{array}{l}\text { Thomas and Mancino (2007) not cited in text. Please add text } \\
\text { citation or the reference will be deleted. }\end{array}$ & \\
\hline
\end{tabular}

